\title{
Crime Trends among Youth
}

\author{
S. Rajalakshmi
}

\begin{abstract}
We read headlines about crime has become a day today affair for us. Our country is affected with many socio-economic problems such like poverty, terrorism, illiteracy and corruption. There is an emergency to overcome these problems by youth is very important. Sociologists and criminologists have been broadly concerned with locating the cause of crime and analysing the effectiveness of the criminal justice system. Parental conflict, broken families, child abuse, poor parental supervision and it leads to carefree attitude of youth in schools and colleges may cause for Violent Behaviour. Separate corrective homes may be established for such criminal youths as are not considered a threat to society. Reshaping of police sub culture, through police organisation, and the professionalization of the police force are necessary for winning confidence and cooperation of the young criminals. New work programmes may be introduced in prisons for training youths to help them in economic rehabilitation.
\end{abstract}

Keywords--- Crime, Criminal Law, Society, Violent Behaviour, Young Criminals

\section{AIM}

$\mathrm{T}$ HE aim of this study is to find the causes and rehabilitative measures of crime trends among youth.

\section{OBJECTIVES}

1) To understand the socio-economic condition of the young offenders.

2) To find out the different types of young criminals based on their personalities.

3) To analyse the factors influencing crime trends.

4) To identify the causes of crime rates increased among youth.

5) To suggest the ways and means to rehabilitate young offenders and deduct the crime rate.

\section{INTRODUCTION}

Sociologists and criminologists have been broadly concerned with locating the cause of crime and analysing the effectiveness of the criminal justice system. In recent times, some researchers have concentrated on enactment of laws, improvement of police system, protecting the interests of victims, improving the condition in prisons.

\section{THEORETICAL EXPLANATIONS OF CRIMINAL BEHAVIOUR}

i) Biogenic Explanation: Many Anthropologists and psychiatrists have opined that the criminals have different physical type than the non - criminals.

ii) Psychogenic Explanation: The psychological theory emphasis low mindedness (Low IQ) and the psychiatric theory on the mental disorders.

iii) Psychological Explanation: Henry Goddard said that low IQ is inherited. He pointed out that a offender is not born but made. At the same time, he believed that every feeble minded person was not a criminal. There are two factors which determined one who become the potential criminal; So though feeblemindedness may be hereditary but criminality is not like that.

iv) Psychiatric Explanation: An leading psychiatrist in Chicago, have different opinions comparatively with his physician colleagues that juvenile delinquency was caused by personality defects as the cause of crime.

v) Psycho analytical Explanation: Sigmund Freud, who developed the psycho- analytical theory at the end of the nineteenth and the beginning of the twentieth century, did not advance a theory of criminality. His approach and three elements such like Id, ego and super ego are used by others like Adler and Fried lander to explain criminal behaviour.

vi) Socio genic Explanation: Sociologists argued that criminal behaviour is learned and it is influenced by the social environment.

vii) Economic Explanation: Italian scholar Fornasaw who discussed of the linkage between crime and poverty in 1884. Sutherland has also said that:

- We find more criminals in poor families because it is easy to locate them,

- Criminals those belong to upper class, they utilize their power and pressures in escaping from legal punishments. The favourism towards the upperclass people, is paid by the administrations.

viii) Geographical Explanation: One kind of explanation denotes some geographical factors like climate and temperature.

S. Rajalakshmi, Assistant Professor, Department of Sociology, The Madura College (Autonomous), Madurai, Tamil Nadu, India.

DOI: 10.9756/IJRAS.8123 


\section{Characteristics of Youth Crime and Young Criminals}

- For the crimes such like murder, rape etc are need more physical energy than other crimes such as theft.

- Young criminals have no powerful encouragement to gain higher standard of life, and they do not suffer for higher social status.

- Youth are more mature socially and mentally when compare with juveniles.

- Youth have aspirations such like occupational, economic, marital and career, while juveniles have no aspirations. And also adults have marital and familial responsibilities and youth have few which mentioned above.

- Adults comparatively free from family dominance while compare with young offenders.

\section{Five Categories of Youth Criminals}

1. Minor Perverts: Those who are involved in petty offences and have economic and/or personal problems and for whom imprisonment would serve no purpose.

2. Victims of Harassment: Those who participate only to a small degree, if at all, in crime and who identify mainly with social norms, and who generally subordinate personal interests to group goals.

3. Tough and deviants. Those who participate to a higher degree in crime and identify with illegitimate standards.

4. Integrated: Those who deviate from others under specific circumstances and who, when arrested, interrogated and imprisoned, maintain dignity while enduring the problems of humiliations and tribulations.

5. Manipulators: Those who manipulate the powers that be not through skill and wit but with high deceit and dishonest tricks and manage to get some facilities and privileges illegitimately.

\section{Inverted U-Curve Adjustment Phenomenon in Youth behaviour}

The deviant behaviour of a youth, as stated earlier, is the result of him maladjustment and the breaking or weakening of social bonds with family and other groups. The adjustment pattern of a youth in 16- 25 years age group may be described as "Inverted U - Curve Phenomenon". When a youth considers himself ready to take up a job, ready to settle in life, ready to undertake responsibilities of life, and ready for enjoying material advantages of society, it is the top of the "Inverted U- Curve". When his situation is suddenly affected by a failure to get a job, by being falsely implicated and accused of some action not committed, by a sudden jolt in life, or by the many practical problems of adjusting to existing environment, he gets the shock of his life.

It is the lowest point of the "Inverted U Curve", the time when appointments in youth's life seem most unbearable, when the feeling of achieving something special in life is worn off, and the past is remembered for its dreams of imminent successes, for its sunlight and not for its shadows. Thus, starting from the 'low' point immaturity and inexperience, he reaches the 'top' point of going to achieve success and then falls down again to the low point of violating the Law. The "Inverted U-Curve Phenomenon" thus explains the maladjustment of a youth in life resulting in violation of social norms and laws.

\section{On the basic of their Personality Type, Criminal Youths may be Classified as Under}

- Pseudo Criminals: Those who may commit a criminal act but are not seriously out of social control. Their criminality is only incidental to the central problem they represent namely, failure of society at large.

- Amoral Criminals: Those who have somehow failed to internalise and fully accept the moral principles of their socially - oriented families and sub culture.

- Real Criminals: Those who have imbibed criminal values and do not suffer from any guilt- feeling when violating the law.

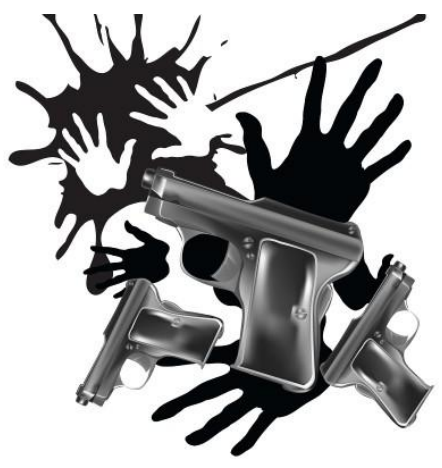

\section{Causes of Youth Crime}

Basically crime is the product of various adverse of social, economic, cultural and family conditions. These causes may differ from country to country; Because, we have various cultural, economic, social characteristics. The causes of crime are primarily related to:

\section{i. Economic Situation \\ ii. Social Environment \\ iii. Family Structures}

\section{i. Economic Situation}

The major economic factors that contribute to the crime ini tiations are Poverty, Unemployment and Political Situation.

- Poverty and Inequality: The persons involved in criminal activities, who are financially weak. A poor father may not be able to educate his children in schoo 1 and lack of education may lead to criminal thinking $o$ $\mathrm{f}$ a child. Homelessness causes the children to spend $\mathrm{m}$ ost of the time on streets.

- Unemployment: Lack of employment opportunities leads to criminal activities amongst the unemployed. Due to unemployment, a person however needs to lead his family; he does not care for any legal matters.

- Political Conditions:

- Due to political instability, people get insecurity in their life and having hopeless in life; so they indulged in unfair means of earning. 


\section{ii. Social Factors}

If we focus, social factors, we must analyse the different environment scenarios of social environment. The core Social root causes of crime are:

- Inequality

- Not sharing power

- Lack of support to families and neighbourhoods,

- Real or perceived inaccessibility to services,

- Lack of leadership in communities,

- Low value placed on children and

- Individual wellbeing, the overexposure to television as a means of recreation.

\section{iii. $\quad$ Social Environment}

There is need to study school environment and community environment which are associated with social environment.

\section{Causes related to the School Environment are}

- Disruptive Behaviour of a child

- Lack of commitment in school

- Community Environment

Major causes of Crime related to Community Environment are

- Lack of cohesion in the society

- Disorganization and neglect especially for Youth

\section{INCREASE IN YOUTH CRIME A TICKING TIME BOMB IN INDIA}

For the past few years, criminal incidents which are involved by young people. We can't judge poorer alone committed crime; but also by rich. As per the latest figures from the National Crime Records Bureau, youth in the age group of $18-30$ were responsible for 41 percent of the total heinous crimes - murder, rape, burglary and kidnapping in 2002.Following caused for Parental conflict, broken families, child abuse, coupled with the carefree attitude of youth in schools and colleges.

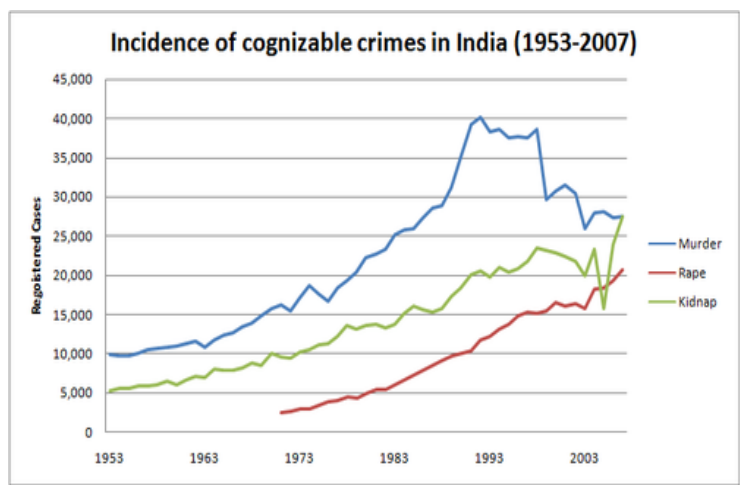

Incidence of cognisable crimes in India 1953-2007.

A report published by the National crime records bureau.

\section{Prevention}

The government is taking the following measures to prevent young offenders from re-offending:

- Personalised approach: The need or support every young person is different; for eg, an aggressive person can be suggested that to learn how to cope with and control aggression. The behaviour change accreditation committee evaluated the desired changing effect.

- Training and education: After their imprisonment, they should go for schooling and college life then settling over searching job. The training and education programmes bring the end of the custodial period help them to reframe.

- Proper support and guidance: The child protection board, youth probation service and municipalities have to protect and give the basic needs for young offenders after releasing.

\section{Crime Prevention Strategies}

- General programmes

- Local community organizations

- Organised recreation

- Case work with their near delinquents

- Group work with near delinquents.

- Institutional modification.

- Institutional reorganisation.

\section{Prevention Policies}

- As we find out more about more about criminal behaviour and crime, we shall have a better basis for interventionist policies. These policies, if carried out consistently, would protect society from crime in three ways.

- First of all we would protect persons who have demonstrated and involving in crime activities. This protection does not reform these offenders, but it will protect society by incapacitating them by directing disapproval of serious deviance from legal aspects.

- Second, these policies would integrate into lawabiding society a larger proportion citizens including the vast majority of those who have committed crimes; but have not demonstrated that they are serious threats to the anti-criminal.

- Third, these policies would define and identify the social situations from which crimes are most likely to issue, and would make it possible to attack and eliminate those social situations. A low crime rate is a desirable social objective.

\section{Protective Factors}

All the persons who have risk factors, may not become young offenders. Some of the positive influence can rectify all the negative influences. Better to avoid anti - social peers and Creating mutual healthy relationships, community interactiveness and sense of Self Esteem are more effective. Improving the household income or improving parenthood rearing practices. There should be rightly framed to remove risk factors for offenders. 
Youth Court Indicates that the following Elements in a Young person's Life will Reduce their Risks

- Girls tend to moderate the risk of boys.

- Family stability promote strong family bonds, love and two parents together.

- Good parenting skills- reasonable rules, consistent consequences and monitoring where the young people are who their friends are.

- School participation.

- Community involvement - active involvement in sports, cultural, religious groups will keep them busy and foster pro- social skills.

\section{RESULTS AND DISCUSSION}

- Separate corrective homes may be established for such criminal youths as are not considered a threat to society.

- Indeterminate sentence system may be introduced for young criminals sent to prisons or Correctional Homes.

- Reshaping of police sub culture, through police organisation, and the professionalization of the police force are necessary for winning confidence and cooperation of the young criminals.

- $\quad$ Legal aid may be provided to poor youths and legal aid organizations may be expanded.

- Judicial officials may be given power of summary trial with regard to certain petty offences of young criminals (under 25 years of age) to as to avoid the moral dangers of detaining them in prison for long periods without trial.

- The courts may be restructured for providing appellant facilities.

- Class - bias may be contained as far as possible in trials.

- New work programmes may be introduced in prisons for training youths to help them in economic rehabilitation.

\section{CONCLUSION}

Youth persons' life is covered with various risk factors and youth crime is not caused by any easily identifiable factors. Different individuals respond to those risk and protective factors in different ways. Life skill interventions must be undergone by the youth offenders; it is the real remedial social skill and it will reduce future committing crimes and deal with conduct deviate social norm issues, any drug and alcohol problems. Policies, attitudes and actions change with the wisdom acquired over the years. The criminal youths who are only in early and mid- twenties of their life have a feeling that the best is "yet to be". Opportunities have, therefore, to be provided to them for social functioning.

\section{METHODOLOGY}

The study is based on secondary data. The secondary data required for the study was collected from various books, magazines, journals, newspapers etc.

\section{REFERENCES}

[1] Ahuja, Ram, Criminology,Rawat Publications, Jaipur, India, 2010

[2] Ahuja, Ram, Social problems in India, Rawat Publications, Jaipur, India, 1997.

[3] Ahuja, Ram, Sociological Criminology, New Age International Publishers, New Delhi, 1996.

[4] Ahuja, Ram, The Prisoner is a Human - being," Times Weekly, Times of India, Bombay, May 27, 1973.

[5] Ahuja, Ram, Youth and Crime, Rawat Publishers, Jaipur, 1996.

[6] Bloch, Herbert A., Man, Crime and Society, Random House, New York, 1956.

[7] Clemmer, Donald, The Prison Community, Christopher Publishing House, Boston, 1940.

[8] Clinard Marshall, B., Sociology of Devinnt Behaviour, Holt, Rinchart and Winston, Inc., Newyork, 1955.

[9] Crime in India,National Crime Records Bereau,Government of India, New Delhi.

[10] Crime in India,1994, National Crime Records Bureau, New Delhi.

[11] Current Perspectives on criminal behaviour, Abraham S. Blumberg, Library of congress cataloguing in Publication Data, New York, 1974.

[12] Edwin H. Sutherland, and Donald R. Cressey, Criminology, J.B.Lippincott Company, New York, 1978.

[13] Inter - Agency plan for current Disorder / Severe anti social behaviour published by the Ministry of Social development ( 2007).

[14] Krishna Iyer V.R, Perspectives in Criminology, Law and social change, Allied Publishers private Limited, New Delhi, India, 1980.

[15] Landis, Paul, Social Problems, J.R. Lippincott Company, Chicago, 1959.

[16] Madan G.R. ,Indian Social Problems ( Vol - I ) Seventh Edition, Allied Publishers Pvt Ltd, New Delhi, 2009.

[17] Mc. Laren, K( 2000) tough is not enough. Published Ministry of Youth Affairs.

[18] Police Crime Statistics.

[19] Trowler, Paul, Active Sociology, 1987.

[20] Wilkins, Leslie T., SocialDeviance: Social Policy, Action and Research, Englewood Cliffs, New Jersey, 1965. 